\author{
Michał Jas \\ Uniwersytet Jana Kochanowskiego w Kielcach \\ ORCID: 0000-0003-4258-9127
}

\title{
Patostreaming - ciemna strona internetu. Analiza zjawiska na wybranych przykładach
}

\begin{abstract}
Streszczenie
Media społecznościoue zmieniają się cały czas, przynosząc nowe problemy badawcze. Jednym z nich jest zjawisko patostreamingu, który jest efektem rozwoju mediów społecznościowych. W artykule dokonano próby scharakteryzowania tego zjawiska: wychodząc od założeń teoretycznych patologii społecznej do analizy wybranych materiałów wideo. Celem artykułu było określenie, czym jest patostreaming i czym się charakteryzuje to zjawisko. Wykorzystano w nim studium przypadków oraz metodę obserwacji.
\end{abstract}

Słowa kluczowe: patostreaming, media społecznościowe, patologia społeczna, internet, nowe media.

\section{Patostreaming - the dark side of the Internet. Analysis of the occurence on selected examples}

\begin{abstract}
Social media are changing all the time, bringing new research problems. One of them is the phenomenon of patostreaming, which is the result of the development of social media. The article attempts to characterize this phenomenon: starting from theoretical assumptions of social pathology to the analysis of selected video materials. The purpose of the article was to determine what patostreaming is and what it characterizes. Method case study and observation were used in this article.
\end{abstract}

Keywords: patostreaming, social media, social pathology, internet, new media.

\section{Wprowadzenie}

Wychodząc od ujęcia definicyjnego patostreamingu ${ }^{1}$, można intuicyjnie stwierdzić, że jest to frazeologiczne połączenie patologii i streamowania (nadawania, głównie na żywo, za pomocą nowych mediów). Syntetyczna i hasłowa definicja mogłaby zatem uyglądać u ten sposób: patostreaming - nadawanie patologicznych treści.

Problematyka związana z tym zagadnieniem była także poruszana $\mathrm{w}$ mediach tradycyjnych. Okres popularności patostreamingów w Polsce przypadł na wiosnę 2018 roku,

${ }^{1}$ Obok określenia patostreaming funkcjonuje synonimicznie patostream. 
kiedy to policja zatrzymała Gurala ${ }^{2}$ - jednego z czołouych polskich patostreamerów. Poustało od tego czasu wiele artykułów prasowych, programów publicystycznych, aby przede wszystkim wykazać opinii publicznej zagrożenia związane z tym nowym zjawiskiem i ustrzec przed takimi treściami ${ }^{3}$.

Celem artykułu jest próba ogólnego scharakteryzowania patostreamingu. Praca stanowi początek badań nad tym zjawiskiem. Materiały wideo, które pojawiły się u części empirycznej, zostały dobrane celowo, a każdy z przykładów jest reprezentantem jednej z kategorii: agresja słowna, agresja fizyczna, libacje alkoholowe, seks/erotyka oraz inne ${ }^{4}$. Wszystkie analizowane filmy bądź fragmenty filmowe były zamieszczone na serwisie YouTube $^{5}$. Z kilkugodzinnego materiału obejrzanego na YouTube ${ }^{6}$ uybrano celowe przypadki, które stanowiły egzemplifikację dla swoich kategorii.

Wykorzystanie w tej pracy studium przypadku (ang. case study) oraz metody obserwacji pozwoliło ustępnie nakreślić złożoność problemu badawczego. Autor ma jednak świadomość, że zjawisko wymaga dalszych pogłębionych badań jakościouych oraz ilościowych. Treść artykułu może stanowić punkt wyjścia do kolejnych prac badawczych, których przedmiotem zainteresowań jest zjawisko patostreamingu.

Badania nad zjawiskiem nadawania patologicznych treści nie są często podejmowane na łamach zagranicznych czasopism. Jedną z czołouych publikacji w literaturze angielskiej jest artykuł Erica F. Glassyego The rise of the social pathologist: The importance of social media to pathology, w którym stwierdza, że media społecznościowe dały możliwości dla stworzenia nowej generacji patologów ${ }^{7}$. Z kolei inni naukoucy skupią się zazwyczaj na idiograficznych aspektach patologii społecznej, które są związane z funkcjonowaniem mediów ${ }^{8}$.

2 Zachowano oryginalną pisownię.

${ }^{3}$ Np. Program Uwaga!, TVN, 14.04.2018 oraz 18.09.2018, Program Alarm!, TVP 1, 21.08.2018, Polsat Neus, (dostęp: 17.02.2019), https://wuw.polsatnews.pl/wideo/wyzwiska-bojki-i-alkohol-patostreamerzy-zarabiaja-nawet-kilka-tysiecy-zlotych-w-jeden-wieczor_6736408/ (dostęp: 14.11.2019). B. Rogouska, A. Pucułek, Youtuber, który chwalit morderstwo prezydenta Pawła Adamowicza, zatrzymany. I to podczas relacji na żywo, „Gazeta Wyborcza. Łódź” 18.01.2019, https://lodz.uyborcza.pl/lodz/7,35136,24376430,youtuber-ktory-chwalil-morderstwo-prezydenta-pawla-adamouicza.html (dostęp: 14.11.2019), A. Jankouska, Na końcu internetu, „Wprost” 06.05.2018, https://www.wprost.pl/tygodnik/10122484/na-koncu-internetu.html (dostęp: 14.11.2019).

${ }^{4}$ Poszczególne kategorie zostały dobrane na podstawie teorii patologii społecznej, obserwacji zjawiska patostreamingu oraz obejrzanych materiałów dostępnych na serwisie YouTube.

${ }_{5}^{5}$ Należy jednak pamiętać, że nie zausze YouTube stanowił pierwotny, docelouy kanał nadawczy patostreamerów. Transmisje były nagrywane z innych źródeł przez widzów, a dopiero później zostały opublikowane na serwisie YouTube.

6 Zob. więcej wpisując w wyszukiwarkę YouTube frazy np. „patologia”, ,patostremer”, „Gural”, „Magical”, „Major Suchodolski”, „Rafatus”. Wpisując słowo „patostreamy”, znajdziemy kilka tysięcy materiałów wideo.

7 E.F. Glassy, The rise of the social pathologist: The importance of social media to pathology, "Archives of Pathology \& Laboratory Medicine” 2010, nr 10(134), s. 1421-1423.

${ }^{8}$ Warto tu przytoczyć takie publikacje jak: C.E. Bair i in., Does the Internet function like magazines? An exploration of image-focused media, eating pathology, and body dissatisfaction, „Eating Behaviors” 2012, nr 4(13), s. 398-401; S.A. King, A. Barak, Compulsive internet gambling: 


\section{Patologia społeczna}

Patostreaming, będąc pojęciem złożonym z dwóch komponentów: patologii oraz streamowania, ma dychotomiczną proweniencję. $Z$ jednej strony jest to zjawisko ściśle związane z socjologią (ponieważ mamy do czynienia z zagadnieniem patologii społecznej), z drugiej zaś patostreaming wpisuje się w problematykę medioznawczą, nośnikiem patologicznych treści jest bowiem w tym przypadku internet, a mówiąc precyzyjniej: nowe media. Aby lepiej zobrazować problem badawczy, należy wyjść od socjologicznego ujęcia patologii społecznej.

Słounik języka polskiego podaje dwie definicje patologii. Pierwsza to: „nauka badająca ogół zagadnień dotyczących przyczyn, mechanizmów i skutków chorób”. Natomiast drugie znaczenie brzmi: „[patologia to - przyp. M.J.] dewiacja, odchylenie od regul".

Słowo „patologia” wywodzi się z greki (pathos) i oznacza „cierpienie”, a dzięki komponentowi logos patologia to nauka o cierpieniu, chorobach. Warto zauważyć, że patologia to róunież dziedzina medycyny, która zajmuje się badaniem poustawania, rozwoju oraz skutków chorób, a specjalista z zakresu patologii jest patologiem. Poprzez taką asocjację patologia społeczna oznacza chorobę organizmu społeczeństwa. Przujmując, że dane społeczeństuo jest zdrowym organizmem, uszystkie wynaturzenia, odmienności w nim się objawiające, stają się „chorobą”, czyli patologią.

Pierusze wzmianki na temat patologii społecznej w ujęciu naukowym pojauiają się z końcem XIX wieku, a jej rozkwit przypadł na XX wiek, kiedy zarówno Europa, jak i Stany Zjednoczone przechodziły intensywny proces industrializacji ${ }^{9}$.

Jednym z czołowych polskich badaczy zagadnienia patologii społecznej był Adam Podgórecki, pozostający dla wielu „twórcą polskiej szkoły patologii społecznej”10. Badacz określa mianem patologii społecznej: „ten rodzaj zachowania, ten typ instytucji, ten typ funkcjonowania społecznego, czy ten rodzaj struktury, który pozostaje u zasadniczej, nie dającej się pogodzić sprzeczności ze światopoglądouymi wartościami, które w danej

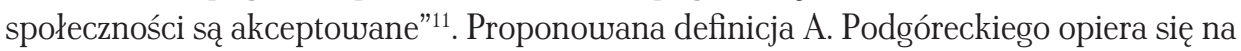
zmiennych wartościach, subiektywizmie. Choć wielu socjologów, widząc mankamenty tej definicji, próbowało dokonać obiektywizacji tego pojęcia, nadając mu naukowego

A New form of an old clinical pathology, „CyberPsychology \& Behavior” 1999, nr 2(5), https:// doi.org/10.1089/cpb.1999.2.441 (dostęp: 28.11.2019). Jedną z pieruszych zuartych publikacji dotyczących patologicznych zjawisk w internecie była: Dont.cons. Crime, deviance and identity on the Internet, red. Y. Jeukes, Willian Publishing, Portland, Oregon 2003. Pozycja stanowi zbiór 10 artykułów, w których omawiono różne przejawy patologicznych zachowań, np. internetowa prostytucja czy stalking.

9 A. Jamrozik, L. Nocella, The sociology of social problems. Theoretical perspectives and metods of interventions, Cambridge Univeristy Press, Cambridge 1998, s. 23.

${ }_{10}$ L. Albański, Wybrane zagadnienia z patologii społecznej, Kolegium Karkonoskie w Jeleniej Górze, Jelenia Góra 2010, s. 7.

${ }^{11}$ A. Podgórecki, Zagadnienia patologii społecznej, Państwowe Wydawnictwo Naukowe, Warszawa 1976, s. 24. 
brzmienia $^{12}$, to jednak brzmienie Podgóreckiego pozostaje u Polsce najpopularniejszą definicją patologii społecznej.

Główne kryterium owych „światopoglądowych wartości” stanowią etyka i moralność. To one rozstrzygają, co jest dobre, a co złe; co moralne, a co moralne nie jest. Za uniwersalizm A. Podgórecki podał „etykę globalną”, obejmującą uspólne zachowania wszystkich narodów. „Ma ona [etyka globalna - przyp. M.J.] służyć jako ostateczna zasada, najuyższa norma" ${ }^{13}$. Podobne stanowisko zajął Andrzej Geberle, pisząc z kolei o „niezgodnych wartościach pouszechnie uznanych w danym kręgu kulturowym”.14.

Inne definicje patologii społecznej traktują ją jako: „wczesną postać dewiacji, opierającą się na poróunaniu organicznym: stwierdzając, że części społeczeństu podobnie jak części ciała, mogą cierpieć na załamania i choroby" ${ }^{15}$. Z kolei na kartach Słownika pojęć socjologicznych można przeczytać, że patologia społeczna obejmuje „wszelkie zjawiska i zachowania destrukcyjne dla życia społecznego"16. Natomiast Maria Jarosz opisuje ją jako „stan zakłócenia społecznej równowagi, charakteryzujący się osłabieniem więzi społecznych oraz rozregulowaniem mechanizmów kontroli społecznej"17. Nieco odmiennie pojęcie to opisał Wincenty Okoń, dla którego patologia społeczna to „nauka o przyczynach, objawach i zwalczaniu takich chorób społecznych, jak przestępczość, pijaństwo, lekomania itd." ${ }^{18}$.

Wraz z rozwojem społeczeństwa: ekonomicznym, gospodarczym oraz demograficznym pojawia się problem zróżnicowania oraz spadek poziomu kontroli społecznej, co w konsekwencji prowadzi do zachowań patologicznych ${ }^{19}$. Prócz owej polaryzacji społecznej, w literaturze przedmiotu można spotkać kilka teorii odnoszących się do przyczyn patologii społecznej. Wymienia się tu: teorię napięć strukturalnych, teorię konfliktu, teorię naznaczenia lub etykietowania, teorię zróżnicowanych powiązań oraz teorię kontroli zwaną zamiennie teorią decydującego wpłyuu ${ }^{20}$.

Pojęcie patologii społecznej jest ściśle związane z funkcjonowaniem społeczeństu. Wielką rolę odgrywały w nim zmiany historyczne, obyczajowe, kulturowe oraz religijne, czyniąc tym samym patologię społeczną „przedmiotem zainteresowania

${ }_{12}$ Encyklopedia socjologii, t. 3 O-R, red. H. Domański i in., Oficyna Naukoua, Warszawa 2000, s. 91.

13 A. Podgórecki, op. cit., s. 639.

14 A. Geberle, Patologia spoteczna, Wydawnictuo Prawnicze, Warszawa 1993, s. 18.

${ }_{15}$ Stownik socjologii i nauk społecznych, red. G. Marshall, Wydawnictwo Naukowe PWN, Warszawa 2004, s. 231-232.

${ }_{16}$ M. Pacholski, A. Słaboń, Słownik pojęć socjologicznych, Wydawnictuo Akademii Ekonomicznej w Krakouie, Kraków 2010, s. 150.

${ }_{17}$ M. Jarosz, Patologia społeczna [w:] Socjologia w Polsce, red. Z. Krawczyk, K.Z. Sowa, Wydawnictuo Wyższej Szkoły Pedagogicznej, Rzeszów 1998, s. 242.

18 W. Okoń, Stownik pedagogiczny, Państwowe Wydawnictwo Naukowe, Warszawa 1981, s. 221.

19 A. Dobiszewski, Przyczyny i przejawy patologii społecznej, „Polityka i Społeczeństuo” 2004, nr 1, s. 154.

${ }^{20}$ Szerzej o tych teoriach zob. J.H. Turner, Socjologia. Koncepcje i ich zastosowanie, przeł.

E. Różalska, Wydaunictuo Naukowe PWN, Poznań 1998, s. 182-186. 
interdyscyplinarnego" ${ }^{21}$. Tworzenie się patologii (indywidualnej oraz kolektywnej) to u głównej mierze upłyu sfery ekonomiczna i politycznej ${ }^{22}$. Do głóunych przejawów patologii społecznej zalicza się ${ }^{23}$ : zachowania agresyune, przemoc (w tym także cyberprzemoc), alkoholizm, narkomanię, samobójstwo, prostytucję, sekty oraz subkultury.

Współczesna myśl socjologiczna i psychologiczna poszerza nieco tę listę, zauważając tym samym, że obecnie:

coraz więcej procesów i zdarzeń traktuje się jako zjawiska patologiczne, np. uzależnienia od telewizji, uzależnienia od telefonów komórkowych, mówi się o patologii systemów zasilanych przez budżet, patologii pracy, patologii struktur ludności i warunków życia ludności, patologii środowiska naturalnego człowieka, zaburzeniach w stosunkach międzyludzkich, patologii instytucji, mobbingu w pracy, patologii w systemach, środowiskach wytwarzających, ułatwiających lub podtrzymujących patologiczne reakcje jednostek żyjących w tych warunkach ${ }^{24}$.

Zgodnie ze słowami Andrzeja Czerkauskiego i Anny Nowak można dojść do uniosku, że zagadnienie patologii społecznej jest rozległe, a same jej przejauy są różnorodne i złożone. Patologia, stanowiąc odstęp od ogólnie przyjętych norm społecznych, jest nacechowana subiektywizmem, społeczne normy mają bowiem charakter umowny, choć niekiedy skodyfikowany (Kodeks Karny, regulaminy, ustawy itp.). Funkcjonowanie dyferencji społecznych sprawia, że w niektórych krajach praktykuje się bigamię, małżeństua z nieletnimi, a jedzenie psa uchodzi za normę. Kultura, będąc „tym uszystkim, co ludzie czynią, myślą i posiadają jako członkowie społeczności”"25, uraz ze suoją etyką i moralnością narzuca u obrębie społeczności wartościowanie: to jest dobre, a to jest złe. Dlatego kultura, czyli „obowiązujący wzorzec działania i myślenia”26, ma realny wpływ na postrzeganie patologii społecznych.

\section{Patologiczne treści internetowe}

Wraz z pojawieniem się mediów społecznościouych, które są kanałem nadawania patologicznych treści, nastąpiła konwersja recepcji mediów. Wówczas, stuierdzając za Henrym Jenkinsem „ludzie wzięli media we własne ręce”27. Upouszechnienie się nowych mediów było „godziną internetu”28, która w konsekwencji przyniosła

${ }_{21}$ L. Albański, op. cit., s. 8.

${ }^{22}$ R.C. Smith, Society and social pathology: A Framework for progress, Palgrave MacMillian, Cham 2017, s. 12.

${ }^{23}$ Ibidem.

${ }^{24}$ A. Czerkauski, A. Nowak, Wstęp [w:] Wybrane zagadnienia patologii spotecznej. Implikacje teoretyczne, red. idem, Wydawnictuo Uniwersytetu Śląskiego, Katowice 2008, s. 7.

${ }^{25}$ R. Biersted, The social order, McGraw-Hill, New York 1963, s. 129.

${ }^{26}$ P. Sztompka, Socjologia. Analiza społeczności, Społeczny Instytut Wydawniczy Znak, Kraków 2012, s. 291.

${ }^{27}$ H. Jenkins, Kultura konwergencji. Zderzenie starych i nowych mediów, przeł. M. Bernartowicz, M. Filiciak, Wydawnictwa Akademickie i Profesjonalne, Warszawa 2007, s. VII.

${ }^{28}$ A. Pian, L'ora di Internet. Manuale critico di pedagogica informatica, La Nuova Italia, Florencja 2000. 
zupełnie „nowego odbiorcę"29. Odmienny uymiar uczestnictua w zmediatyzowanej rzeczywistości jest spowodowany „wywołaniem zmian społeczno-kulturowych w rozwijającym się społeczeństuie" ${ }^{30}$. Fakt, że media społecznościoue polegają na uymianie, rozpouszechnieniu i tworzeniu nowych treści, powoduje, że między użytkownikami tworzy się pewien rodzaj wspólnotowości ${ }^{31}$.

Wraz z wielkim rozwojem przemian informacyjno-technologicznych, które przyniosły w konsekwencji upowszechnienie internetu, to media społecznościowe stały się „nośnikiem” lub „strumieniem” (ang. stream) napływu patologicznych zjawisk i treści. Przeciętny, przypadkowy użytkownik sieci mógł zostać widzem scen pełnych agresji słownej i fizycznej, rejestracji libacji alkoholowych, scen seksu.

\section{a) agresja słowna}

Agresja słowna stanowi jeden z popularniejszych wyznaczników patostreamingu. W niej zawierają się uulgaryzmy, przekleństwa, wyzwiska, a czasami nawet i groźby popełnienia przestępstwa.

Jednym z przykładów należących do kategorii agresji słounej może być fragment materiału, w którym dwóch bezrobotnych wspólnie mieszkających mężczyzn w taki sposób ze sobą rozmawia. Rozmowę jeden z nich nagrywa, po czym wideo trafia na kanał na YouTube ${ }^{32}$. Zaznaczmy tylko, że kanał każdego z nich śledzi prawie 100 tysięcy użytkouników.

Wojtek: No dzień dobry, ogółem. Chciałem ogółem dla was ogółem powiedzieć. Dzisiaj Krzysztof Kononowicz chciał mnie wyrzucić. Dzisiaj jest niedziela, chciał uyrzucić mnie z domu...

Krzysztof: Pouviedz prawdę za co.

W: Jak za co?

K: Powiedz praudę.

W: A co ty nagadałeś na mnie? Że ja narkoman jestem jakiśs kurwa i nie wiadomo co. Że w majtki nasrałem, kurwa. Jak ja kurwa byłem w szpitalu. I chce mnie do Choroszczy [tamtejszy Zakład Psychiatryczny - przyp. M.J.] wysłać. Ciekawe za co. Jak ja trzeźuy jestem. K: Za narkomanię. [...]

\section{b) agresja fizyczna}

Agresja fizyczna stawowi poważny problem patostreamingu, ponieważ narusza nietykalność drugiej osoby. Napiętnowane przez widzów są częściej materiały, w których patostreamer znęca się fizycznie i psychicznie nad swoją matką lub babką.

\footnotetext{
${ }_{29}$ A. Kowalska, Nowy odbiorca? Przemiany obrazu odbiorcy w wybranych koncepcjach wspótczesnej kultury, Oficyna Naukowa, Warszawa 2014.

${ }^{30}$ A. Mitra, New media and convergence: A development communication perspective, „Global Media Journal - Indian Edition" 2011, nr 2(2), s. 3.

${ }^{31}$ M. Deunig, Les médias sociaux - Introduction, Ottawa 2012, Bibliothèque du Parlement, Ottawa 2012, https://lop.parl.ca/sites/PublicWebsite/default/fr_CA/ResearchPublications/201003E (dostęp: 26.11.2019).

${ }^{32}$ https://wuw.youtube.com/watch?v=Zugflx1uiv0 (dostęp: 14.11.2019).
} 
Przytoczony fragment zapisu relacji patostreamingu Proboszcza, który pobija swojego kolegę Małysza, stanowi przykład agresji fizycznej, będąc jednocześnie skrajnym przejawem patostreamingu nadawanego online ${ }^{33}$.

M: Co ty kurwo powiedziałeś? (wstaje do Proboszcza)

P: (sięga po pustą butelkę po wódce i wymierza kilka razy ciosów w głowę Małysza).

M: (na kolanach, bity butelkami) Ty kurwo, znowu z butelkami? Znouu z butelkami? Jebana kurwa. (krzyczy) Ała, ała, ała!

Małysz leży na podłodze i krzyczy bity butelką po głowie przez minutę.

M: Ała, już! Kurwa mać! Zostaw już, kurwa! Stop [...]

\section{c) libacje alkoholowe}

Patostreamerzy często są kojarzeni z nałogami. W udostępnianych materiałach wideo lub na transmisjach widać ich $\mathrm{w}$ towarzystwie alkoholu wysokoprocentowego. Zazwyczaj jest to wódka. Rzadko zdarzają się narkotyki ze względu na nielegalność ich posiadania. Imprezy alkoholowe, zwane również libacjami, stanowią tło, bazę, punkt wyjścia do innych późniejszych zjawisk: agresji słownej, scen seksu czy bijatyk. Przyoczony zapis transmisji Daniela Magicala przedstawia patostreamera, który chwali się uypitą ilością wódki naraz ${ }^{34}$.

Daniel Magical: (podnosząc pustą szklankę do kamery) Jaca [współbiesiadnik, kolega Daniela - przyp. M.J.] mi szklankę przyniósł. (Daniel odkręca butelkę wódki i wlewa ok. $50 \mathrm{ml}$ do szklanki). Pa Jaca. Co ty kurwa robisz? (Podaje szklankę koledze) Zazdrosna kurwa jesteś? Że on też może pić? Kurwa, pojebało cię? (Napełnia z uśmiechem kolejną szklankę wódką.) No. No. (W tle słychać głośno muzykę i nie da się zrozumieć słów współbiesiadników).

\section{d) seks/erotyka}

Do tej kategorii należą uszystkie sceny, które wykorzystują sferę seksualną. Istnieje wiele materiałów wideo, w których patostreamerzy uprawiają seks lub odnoszą się do niego u sposób im ułaściuy. Jeden z nich na przykład za 50 złotych przed kamerą ogolił swoje włosy łonowe. Za dobry przykład $w$ tej kategorii zachowań patologicznych może posłużyć rozmowa Rafatusa ze suoją dziewczyną Marleną ${ }^{35}$. Nota bene, para wielokrotnie uspółżyła na oczach widzów. Z późniejszą dzieuczyną Agnes Rafatus również uprawiał seks przed kamerą. Do sieci przedostało się nawet nagranie, w którym Agnes guałci analnie Rafatusa straponem ${ }^{36}$.

Marlena: Mam smaczka na robaczka. Chcę ci zrobić lodzika z połykiem. Zgadasz się? Chwila ciszy, Rafatus wypił łyk alkoholu.

Rafatus: No, no, no, no, no.

M: No co „no"?

${ }^{33}$ https://wuw.youtube.com/watch?v=M1MmouQlfNc (dostęp: 14.11.2019).

${ }^{34} \mathrm{https} / / /$ www.youtube.com/watch?v=hjz5C6Snlo8 (dostęp: 14.11.2019).

${ }^{35}$ https://wuw.youtube.com/watch?v=FQhjumSjAo0 (dostęp: 14.11.2019).

${ }^{36}$ Rodzaj zabawki erotycznej. Jest to wykonany z plastiku penis. 
Michał Jas

R: Popierdoliło cię ty kurwo? Tam masz obuodnicę. Chcesz się kurwić to wypierdalaj. M: Nie... (uśmiecha się do chłopaka)

\section{e) inne}

Do „innych” należy zaliczyć uszystkie pozostałe materiały wideo, które, nie będąc w żadnej z wcześniej wymienionych kategorii, w swojej treści promują zachowania patologiczne (sprzeczne z pouszechnie przyjętymi uniwersalnymi zasadami moralności) lub stanowią jej inklinację. Przykładem filmu, który jest wyrazem skłonności zachowań patologicznych może być nagranie duunastoletniej dziewczynki, która u piosence „Narcyz pedau ${ }^{37 ”}$ obraża swojego starszego brata. To wideo, dostępne powszechnie na YouTube, uyśuietlono prawie 6,5 miliona razy. Bohaterka filmu tak śpiewa:

ej, Narcyz, grubasie, ile ty masz u pasie

ale ty masz pryszczaty ryj

szkoda, ze tego w kamerze nie widać

Ref: Nikoś ty żryj kupę, żryj kupę

bo dostaniesz mocno kopa w dupę

kopa w dupę

nawet nie uiesz co to prestiż

śmierdzisz

i do tego głośnie pierdzisz

Nikoś ty żryj kupę, żryj kupę

bo dostaniesz mocno kopa u dupę

kopa w dupę

nawet nie wiesz co to prestiż

śmierdzisz

i do tego głośnie pierdzisz

$[\ldots]$

\section{Widownia patologicznych seansów}

Każdy patostreamer ma swoją wierną widownię, która na bieżąco śledzi jego poczynania. Aktywność widzów przybiera różne formy. Można z nich wyróżnić:

- komentowanie,

- wpłacanie pieniędzy w trakcie transmisji (tzw. donejty),

- odwiedzanie patostreamerów (często w trakcie transmisji, mając realny upłyu na jej przebieg),

- wysyłanie różnych przedmiotów (mogą to być listy, odzież, pożywienie, alkohol, a nawet tona węgla),

${ }_{37}$ Zachowano pisounię oryginalną. https://www.youtube.com/watch?v=2GhxnlUJSGs (dostęp: 14.11.2019). 
- podejmowanie konkretnych działań wobec nadawców treści patologicznych (np. zawiadamianie policji lub pogotowia ratunkowego, a nawet, $\mathrm{w}$ formie żartu, zawiadamianie zakładu pogrzebowego o rzekomej śmierci).

Widownię patologicznych seansów można podzielić na pozytywną i negatywną. Widounia pozytyuna gloryfikuje działania, które są przedstawiane na tych materiałach, wyrażając się o nich z pełną aprobatą. Pod filmami, których fragmenty zostały zaprezentowane $u$ artykule, można przeczytać takie pochwalne komentarze ${ }^{38}$ : „Po prostu uczeń przerósł mistrza, sorki Narcyz taka prawda..”, „zqjebiste, nagrywaj wievej xd”, "Czemu ten film nie ma 5000 milionów”, „Twoja siostra to uygryw, to u was rodzinne jak widać”. A także: „Hahahahahaha wkońcu coś porządnego”, „Kurwa, znam to już na pamięć XD”, „Moja ulubiona kurwica boża Kaj00ra”, „Kłócą się jak typowe stare małżeństuo Grażynki i Janusza z piętra w bloku” czy nawet: „Dobrze, że mu w końcu mocno zajebał".

Widownia negatyuna cechuje się wrogim nastawieniem do prezentowanych treści. W komentarzach wyrażają swój sprzeciu na internetową działalność patostreamingu. Pod filmami, których fragmenty zostały przedstawione, można przeczytać między innymi: „Za kogo ty się uważasz dziecko lepiej się ucz”, „Pytanie, gdzie są rodzice , bo nie sądzę , żeby byli z tego dumni”, „tylko dzieci z rakiem mózgu tego słuchają”, „To już kurwa nie jest śmieszne...”, „Okropne czy zdajecie sobie sprawę ze mogło dojść do morderstua tle ciosów u głowę tępym narzędziem i duszenie.... Znacie takie pojęcia jak Empatia i Współczucie?”, „Ja to nie rozumie jak można im płacić za to, dno i wodorosty".

Patostreamerzy funkcjonują jedynie dzięki suojej widowni, która umożliwia im przetruanie. Ponieważ u głównej mierze nadawcami treści patologicznych są osoby niepracujące, to każde wsparcie widzów (w formie gotówkowej lub zmaterializowanej) jest dla nich ważne. Bez widowni żaden patostreamer nie mógłby funkcjonować. Naturalnie brak widzów nie zniweluje zjawiska patologii społecznej, ale takie materiały wideo nie miałyby wówczas racji bytu w sieci.

\section{Konsekwencje patostreamingu}

Dokonując analizy przywołanych materiałów wideo, można uskazać na duie główne konsekwencje. Po pierwsze, mowa tu o odpouiedzialności wobec prawa. W materiałach patostreameróu można dostrzec karalne działania, między innymi: pobicie, zniesławienie, naruszenie nietykalności, przemoc fizyczną, psychiczne znęcanie się nad drugą osobą. Róunie ważne jest tu łamanie regulaminów stron, które umożliwiają streamowanie. Ten rodzaj konsekwencji dotyczy jedynie twórców takich nagrań.

Druga konsekwencja to psucie moralne. Jak wiadomo, głównymi użytkownikami internetu są osoby młode. Choć istnieje ostrzeżenie „materiał jedynie dla dorosłych widzów", to wystarczy podać jakąkoluiek datę, która sugeruje pełnoletność i młodzi

${ }^{38}$ Komentarze w pisouni oryginalnej. 
widzowie mają pełen dostęp do takich treści. Kontrola rodziców lub opiekunów prawnych jest niemal niemożliwa. Można powiedzieć, że widzowie, oglądając takie materiały, obcują z niemoralnym i zepsutym środowiskiem pełnym agresji, uulgaryzmów, wyuzdania seksualnego. Uczą się też, że bez pracy można funkcjonować na wysokim poziomie. Co więcej, patostreamy, dla niektórych młodych, mogą wydawać się zatem alternatywą na życie i szybkie wzbogacenie się. Jedynym do tego niezbędnym warunkiem jest dostęp do internetu.

Wydaje się jednak, że żadne telewizyjne programy interwencyjne, pogadanki edukacyjne w szkołach nie sprawią, że to zjawisko nagle zniknie. Zamykanie jednego kanału otwiera drugi, koniec jednej strony streamowania oznacza początek drugiej. To, co prymityune, atawistyczne, uulgarne przypomina tu „nagą małpę przed internetem" ${ }^{39}$.

\section{Podsumowanie}

Reasumując, na podstawie założeń teoretycznych oraz bazując na przytoczonych fragmentach filmowych, można powiedzieć, że patostreaming to uszystkie nadawane, upowszechniane i promowane za pośrednictuem nowych mediów treści o proweniencji patologicznej, czyli takie, które kłócą się z akceptowalnością systemu moralnego i etycznego społeczeństwa.

Przedstawione nagrania sugerują, że choć mamy do czynienia z różnymi przejawami patostreamingu (mniejszego lub większego, skrajnego), to uszystkie treści, które promują działalność sprzeczną z systemem etycznym, upisują się u to zjawisko. Dlatego śpiewającą nastolatkę „żryj kupę”, należy podobnie traktować jak sceny pobicia czy pouszechnej gloryfikacji alkoholu. Dyskusja o mniejszej czy większej patologii mogłaby w konsekwencji stanowić ciche przyzwolenie na tworzenie się nowych, niebezpiecznych treści.

Internet stanowi olbrzymią przestrzeń generowanych treści. Znajdziemy u nim niemal odpowiedzi na nurtujące pytania. Dobrze wykorzystywane nowe media mogą zatem przyczyniać się do poprawy wielu sfer życia społecznego (m.in. internet zapeunia nowe miejsca pracy, pluralizm, demokratyzację). Jednocześnie upouszechnienie nowych mediów przyniosło również niepożądane efekty, między innymi: stalking, trollowanie, cracking, hejt czy patostreamowanie. Jednak w przypadku oglądania patologicznych treści to sami użytkounicy internetu dokonują wyboru: oglądać lub nie. Przycisk „play” jest wówczas przepustką do prymitywnej, uulgarnej rzeczywistości, do której nikt na siłę nie zaprasza.

${ }^{39}$ Por. T. Kozłouski, T. Szlendak, Naga małpa przed telewizorem. Popkultura w świecie psychologii ewolucyjnej, Wydawnictwa Akademickie i Profesjonalne, Warszawa 2008. 


\section{Bibliografia}

Albański L., Wybrane zagadnienia z patologii społecznej, Kolegium Karkonoskie u Jeleniej Górze, Jelenia Góra 2010.

Bair C.E., Kelly N.R., Serdar K.L., Mazzeo S.E., Does the Internet function like magazines? An exploration of image-focused media, eating pathology, and body dissatisfaction, „Eating Behaviors" 2012, nr 4(13), s. 398-401.

Biersted R., The social order, McGraw-Hill, Nowy Jork 1963.

Czerkauski A., Nowak A., Wstęp [w]: Wybrane zagadnienia patologii społecznej. Implikacje teoretyczne, red. idem, Wydawnictwo Uniwersytetu Śląskiego, Katowice 2008.

Dobiszewski A., Przyczyny i przejawy patologii społecznej, „Polityka i Społeczeństwo” 2004, nr 1, s. 153-166.

Dont.cons. Crime, deviance and identity on the Internet, red. Y. Jewkes, Willian Publishing, Portland, Oregon 2003.

Encyklopedia socjologii, t. 3 O-R, red. H. Domański i in., Oficyna Naukowa, Warszawa 2000.

Geberle A., Patologia spoteczna, Wydawnictwo Praunicze, Warszawa 1993.

Glassy E.F., The rise of the social pathologist: The importance of social media to pathology, „Archives of Pathology \& Laboratory Medicine” 2010, nr 10(134), s. 1421-1423.

Jamrozik A., Nocella L., The sociology of social problems. Theoretical perspectives and metods of interventions, Cambridge Univeristy Press, Cambridge 1998.

Jarosz M., Patologia społeczna [w:] Socjologia w Polsce, red. Z. Krawczyk, K.Z. Sowa, Wydawnictwo Wyższej Szkoły Pedagogicznej, Rzeszów 1998.

Jenkins H., Kultura konwergencji. Zderzenie starych i nowych mediów, przeł. M. Bernartowicz, M. Filiciak, Wydawnictua Akademickie i Profesjonalne, Warszawa 2007.

Kowalska A., Nowy odbiorca? Przemiany obrazu odbiorcy w wybranych koncepcjach wspótczesnej kultury, Oficyna Naukowa, Warszawa 2014.

Kozłouski T., Szlendak T., Naga małpa przed telewizorem. Popkultura w świecie psychologii ewolucyjnej, Wydawnictwa Akademickie i Profesjonalne, Warszawa 2008.

Okoń W., Stownik pedagogiczny, Państwowe Wydawnictwo Naukoue, Warszawa 1981.

Pacholski M., Słaboń A., Stownik pojęć socjologicznych, Wydawnictwo Akademii Ekonomicznej u Krakowie, Kraków 2010.

Pian A., L'ora di Internet. Manuale critico di pedagogica informatica, La Nuova Italia, Florencja 2000.

Podgórecki A., Zagadnienia patologii społecznej, Wydawnictwo Naukowe PWN, Warszawa 1976.

Program Alarm!, TVP 1, 21.08.2018.

Program Uwaga!, TVN, 14.04.2018 oraz 18.09.2018.

Stownik socjologii i nauk społecznych, red. G. Marshall, red. wyd. pol. M. Tabin, Wydawnictwo Naukowe PWN, Warszawa 2004.

Smith R.C., Society and social pathology: A framework for progress, Palgrave MacMillian, Cham 2017.

Sztompka P., Socjologia. Analiza społeczności, Społeczny Instytut Wydawniczy, Kraków 2012. Turner J.H., Socjologia. Koncepcje i ich zastosowanie, przeł. E. Różalska, Wydawnictuo Naukowe PWN, Poznań 1998. 
Michał Jas

\section{Źródła internetowe}

Dewnig M., Les médias sociaux - Introduction, wyd. Bibliothèque du Parlement, Ottawa 2012, https://lop.parl.ca/sites/PublicWebsite/default/fr_CA/ResearchPublications/201003E (dostęp: 26.11.2019).

Rogouska B., Pucułek A., Youtuber, który chwalit morderstwo prezydenta Pawła Adamowicza, zatrzymany. I to podczas relacji na żywo, „Gazeta Wyborcza. Łódź” 18.01.2019, https://lodz. wyborcza.pl/lodz/7,35136,24376430,youtuber-ktory-chwalil-morderstwo-prezydenta-pawla-adamouicza.html (dostęp: 14.11.2019),

King S.A., Barak A., Compulsive internet gambling: A new form of an old clinical pathology, „CyberPsychology\&Behavior” 1999, nr 2(5), https://doi.org/10.1089/cpb.1999.2.441 (dostęp: 28.11.2019).

Mitra A., New media and convergence: A development communication perspective, „Global Media Journal - Indian Edition” 2011, nr 2(2), https://wuw.caluniv.ac.in/global-mdia-journal/ Winter\%20Issue\%20December\%202011\%20Students\%27\%20Research/SR-3.pdf (dostęp: 14.11.2019).

Jankouska A., Na końcu internetu, „Wprost” 06.05.2018, https://www.wprost.pl/tygodnik/10122484/na-koncu-internetu.html (dostęp: 14.11.2019).

Polsat News, 17.02.2019, https://www.polsatnews.pl/wideo/wyzwiska-bojki-i-alkohol-patostreamerzy-zarabiaja-nawet-kilka-tysiecy-zlotych-w-jeden-wieczor_6736408/ (dostęp: 14.11.2019).

https://www.youtube.com/watch?v=Zugflx1uiv0 (dostęp: 14.11.2019).

https://www.youtube.com/watch?v=M1MmouQlfNc (dostęp: 14.11.2019).

https://www.youtube.com/watch?v=2GhxnIUJSGs (dostęp: 14.11.2019).

https://www.youtube.com/watch?v=hjz5C6Snlo8 (dostęp: 14.11.2019).

https://www.youtube.com/watch?v=FQhjumSjAo0 (dostęp: 14.11.2019). 